\title{
ÁSVÁNYOK STABILITÁSA VIZES OLDATOKBAN - HAZAI PÉLDÁKKAL
}

\author{
Viczián István \\ Debreceni Egyetem, Ásvány- és Földtani Tanszék, 4032 Debrecen Egyetem tér 1. \\ e-mail: viczianif@gmail.com
}

Stability of minerals in aqueous solutions - with examples from Hungary

\begin{abstract}
The paper first reviews the application of physical chemistry of aqueous solutions in mineralogy with special respect to genesis of sedimentary rocks. The stability diagrams, especially those constructed by Lippmann (1979-1982) are reviewed.

The stability - metastability relations of minerals, in particular, clay minerals formed at surface conditions, are discussed according to Lippmann. Two geological examples are presented:

- relationship of dickite and kaolinite in the Mesozoic basement of the Pannonian Basin;

- relative stability of corrensite detected in the Lower to Middle Cretaceous marls and sandstones of Gerecse Mts.

Examples for the application of the diagrams with chemical variables are:

- interpretation of activity values measured in salt affected soils of the Great Hungarian Plain in improved activity diagrams, following Géza Szendrei (1981, 1985), comparison of the results with those obtained by soil science;

- analysis of the possible effect of karst water on red clays found in karstic cavities of Beremend (Villány Mts.)
\end{abstract}

Keywords: stability diagrams, dickite-kaolinite, corrensite-randomly mixed-layered chlorite/smectite, sodic soils, red clays

\section{Összefoglalás}

A dolgozat elöször áttekintést ad a vizes oldatok fizikai-kémiai tulajdonságainak alkalmazásáról az ásványtanban, különös tekintettel az üledékes kőzetek keletkezésére. Részletesebben ismerteti a stabilitási diagramokat, főleg ezek Lippmann által szerkesztett változatait (1979-1982).

A cikk külön tárgyalja Lippmann nyomán a stabilitás - metastabilitás kérdését a felszíni körülmények között keletkezett ásványok, különösen az agyagásványok esetében. Ezekre két földtani példát mutat:

- a Pannon-medence mezozoos aljzatában keletkezett dickit és kaolinit viszonya;

- a gerecsei alsó- és középső-kréta Berseki Márga és Lábatlani Homokkő Formációkban kimutatott corrensit relatív stabilitása.

A kémiai változókból szerkesztett diagramokra két példát mutat be:

- Szendrei Géza $(1981,1985)$ munkáját folytatva az alföldi szikes talajokban mért aktivitás értékek értelmezése az azóta javított diagramokban, az eredmények összehasonlítása az ismert talajtani eredményekkel;

- a beremendi karsztos üregeket kitöltő kaolinos vörös agyagok és a karsztvíz lehetséges kölcsönhatásának vizsgálata. 
Kulcsszavak: stabilitási diagramok, dickit-kaolinit, corrensit-klorit/szmektit véletlen kevert szerkezet, szikes talajok, vörös agyagok

\section{Bevezetés}

Az ásványok, a földkéreg szilárd alkotói vagy nagy hőmérsékletü olvadékból, vagy vizes oldatból keletkeznek, de az olvadékból keletkezett magmás kőzetek kristályosodásában és utólagos elváltozásaiban is nagy szerepe van a víznek. Az ásványok egymás közötti kémiai reakciói is a legtöbb esetben víz közvetítésével folynak le, nemcsak az üledékes, hanem a metamorf kőzetekben is. Mivel a legtöbb ásvány vízben nehezen oldódik, ezeknek a reakcióknak a lefolyásában a hosszú földtani időknek fontos szerepe van. Ezért az ásványok és a víz kölcsönhatásának vizsgálatában már régóta a vizes oldatok kémiai termodinamikája felé fordult a figyelem. Ennek egyik első képviselöje volt az Eskola-féle (1921) metamorf ásványfácies fogalmát továbbfejlesztő Korzsinszkij (1936, 1957), aki már kimondottan a vizes oldatok által közvetített metaszomatikus hatásokat vette figyelembe. Korzsinszkij a kémiai egyensúly külső feltételei közé sorolta a metaszomatikus oldatokban levő ún. tökéletesen mobilis komponensek kémiai potenciáljait is.

Korzsinszkij csak a módszer elméleti alapjait dolgozhatta ki, de az 1960-as években megindult a kísérleti adatok gyüjtése is a természetes viszonyokat utánzó egyszerüsített kémiai rendszerekre. Ezek alapján olyan stabilitási diagramokat szerkesztettek, amelyek azt mutatták, hogy a vizes oldatban levő oldott ionok aktivitása függvényében milyen tartományban milyen szilárd ásványok vannak egyensúlyban az oldattal, azaz milyen ásványok stabilisak. Számos ilyen diagramot publikáltak, az első komolyabb adatgyüjteményt Garrels \& Christ (1965) jelentette meg.

Magyarországon a kémiai termodinamika ásványtani alkalmazásáról először Grasselly Gyula adott ismertetést Koch Sándor és Sztrókay Kálmán Imre Ásványtan könyve 2. kiadásának I. kötetében (1967) „Ásványkémia” cím alatt. Ebben azonban a vizes oldatokkal nem foglalkozik, az alapfogalmak mellett csak az olvadékból való kristályosodást tárgyalja. A vizes oldatok kémiai termodinamikáját üledékes környezetben és talajokban lejátszódó folyamatokra vonatkozóan magyar nyelvű szakkönyvben először Nemecz Ernö (2006) foglalta össze. Szabatosan és mégis érthető módon tárgyalja földtudományi szakemberek részére a kémiai termodinamika alapjait és ásványtani alkalmazásait Varga Andrea (2019) újonnan megjelent egyetemi tankönyve.

E stabilitási diagramok közül a szerző véleménye szerint elméletileg leginkább megalapozottak és a földtani értelmezés terén a legjobban alkalmazhatók a Lippmann által szerkesztett diagramok (szilikát-ásványokra 1979, 1982, karbonátokra 1991). A szilikátokat, főleg agyagásványokat tartalmazó diagramok elméleti alapjait, fogalmait és az üledékes kőzettan legkülönbözőbb kérdéseire való alkalmazását Viczián $(2006,2008)$ ismertette, s külön foglalkozott tudománytörténeti jelentőségükkel is (2011). Egy előadásban pedig a karbonátos diagramokat is áttekintette (Viczián, 2009). Ebben a munkában ezért a módszer részletes ismertetésére nem térünk ki, hanem néhány hazai példán keresztül mutatjuk be a szilikátos diagramok alkalmazhatóságát. A példáknál az ásványtani és földtani részletekre sem térünk ki, hanem csak utalunk a meglevő részletesebb leírásokra. A dolgozat céljának megfelelöen az egyes esetek leírásánál igyekszünk a kémiai termodinamikai szempontokat kiemelni, és a témákat is eszerint csoportosítottuk. 


\section{Ásványok termodinamikai stabilitása}

Lippmann nagy figyelmet fordított még a diagramok megszerkesztése elött az egyes ásványfázisok stabilitásának a kérdéskörére, mert akkor lehet egyértelmü megfelelés a fázisok és az egyensúly tényezői között, ha a fázisok stabilak az adott egyensúlyi tényezők mellett. A reális ásványok között, különösen az üledékes tartományban sok a felszíni hőmérsékleten, pl. $25{ }^{\circ} \mathrm{C}$-on metastabil fázis. A metastabilitás legegyszerübb esete, ha egy adott, egyszerü kémiai képlettel megadható ásványnak több szerkezeti módosulata van. Ezek közül adott hőmérsékleten és nyomáson csak egy lehet stabil, a többi mind metastabil. További okok, hogy a legtöbb háromrétegü (illetve négyrétegü) agyagásvány több stabil komponens szilárd oldata (pl. illit), továbbá ezek az önmagukban is metastabil ásványok még kevert rétegü szerkezeteket is alkotnak egymással (pl. illit/szmektit). Ezek helyett felszíni hömérsékleten és nyomáson is a stabil komponenseik elegye lenne a stabil rendszer. Annak, hogy mégis ezek az agyagásványok keletkeznek, reakciókinetikai okai vannak, föleg a túltelített oldatokból való gyors kristályosodás. Ezért a legtöbb agyagásványnak nem adható meg pontosan a termodinamikai stabilitási tartománya, csak képződésük és fennmaradásuk külső tényezőinek a tartományát adhatjuk meg tapasztalati alapon, több-kevesebb pontossággal. Ez várhatóan a hozzájuk legközelebb álló stabil fázis stabilitási tartománya közelében lesz.

Lippmann az általa szerkesztett diagramokon következetesen megkülönböztette a nevek írásmódjával is a metastabil és stabil fázisokat, pl. stabil: MUSZKOVIT, metastabil: illit, vagy stabil: DIASZPOR, metastabil: Gibbsit (lásd 1-3. ábrák). Később többen kétségbe vonták, hogy az agyagásványokat metastabilnak kell-e tekinteni, de a bírálatokra Aja \& Rosenberg (1992) meggyőzően válaszoltak.

\section{Izokémikus metastabil - stabil átmenet feltételezése: dickit előfordulása a mély diagenetikus zónában a Pannon-medence mély aljzatában}

Az izokémikus stabilitási különbségekre jó példát adnak a kaolin-csoport ásványai is, ahol a halloysit, rendezetlen kaolinit kevésbé stabilak, mint a jól rendezett kaolinit. A rendezett kaolinit és dickit viszonya azonban nem ilyen egyszerü. Az 1. ábrán ez úgy fejeződik ki, hogy a stabil fázisnak tartott DICKIT mezejében egy átmeneti írásmóddal a „Kaolinit” név is szerepel. Lippmann azért tartotta a dickitet a legstabilabbnak, mert az akkor rendelkezésére álló adatok szerint a kaolin-változatok közül ennek volt a legnagyobb a rácsenergiája (a rétegközi OH-kötésekből származó U Coulomb-energia; Giese, 1973). Ugyanakkor hangoztatta, hogy a $\Delta \mathrm{G}_{\mathrm{f}, 298}^{\mathrm{o}}$ Gibbs-féle képződési szabadenergia értékei a két ásvány között hibahatáron belül azonosak, és a dickit stabilitási mezeje gyakorlatilag megegyezik a kaolinit stabilitási mezejével. A földtani tapasztalat az, hogy a kaolin-csoport ásványai közül a kaolinit nagyon gyakori, a dickit ellenben nagyon ritka, és csak nagyobb hőmérsékleten keletkezik.

A kaolinit Magyarországon is nagyon gyakori, de a dickitet csak három lelőhelyen találtuk meg (Viczián, 2019). Mind a három helyen a Pannon-medence mezozoos aljzatában fordult elő, jól rendezett kaolinittel együtt.

A Som-1. fúrásban, a Közép-dunántúli szerkezeti egységben rendszeresen megtalálható az alsó-triász és középső-triász anisusi dolomit és a középső-triász ladin mészkő oldási maradékában, jól kristályos kaolinittel és kevesebb illittel együtt. Jelenlétét a röntgendiffrakciós felvételeken $h k l$-reflexiói alapján, valamint Udvardi Beatrix 2012-ben készült ATRFTIR felvételei alapján lehetett kimutatni (Udvardi et al., 2013; Viczián et al., 2013). Elöfordulása viszonylag nem nagy mélységben van, de elég széles mélységközt fog át, $961 \mathrm{~m}$ és $1500 \mathrm{~m}$ között. A fúrómag minták megfigyelése alapján a rétegsor tektonikusan összetöredezett, a dickit szabad pórustérben, valószínűleg hidrotermális oldatok hatására, 
kaolinitből kristályosodott át. Most is jól kristályos kaolinittel együtt található. A kőzetben eredetileg is kaolinit lehetett az oldási maradék fó ásványa, mert a márgás rétegekben, amelyek valószínüleg kevésbé voltak vízzel átjárhatók, nincs dickit, de a kaolinit megvan.

Az oldási maradék összetétele különbözik a szomszédos szerkezeti egységek középső-triász karbonátos kőzeteitől. A középhegységi és mecseki középső-triászban szinte csak illit van, a kaolinit kevés. A Dunántúli-középhegységben csak a felső-triászban lehet helyenként uralkodólag kaolinit (pl. Vállus Vát-2.), sőt itt bauxit-ásványok is előfordulhatnak (Korpás, 1980). A Közép-dunántúli szerkezeti egységben a közeli Igal-7. fúrásban találtunk hasonló, hidrotermális nyomokra utaló jelenségeket, szintén viszonylag kis mélységben felső-triász nori karbonátos kőzetekben. Itt azonban dickit nem volt, csak kaolinit.

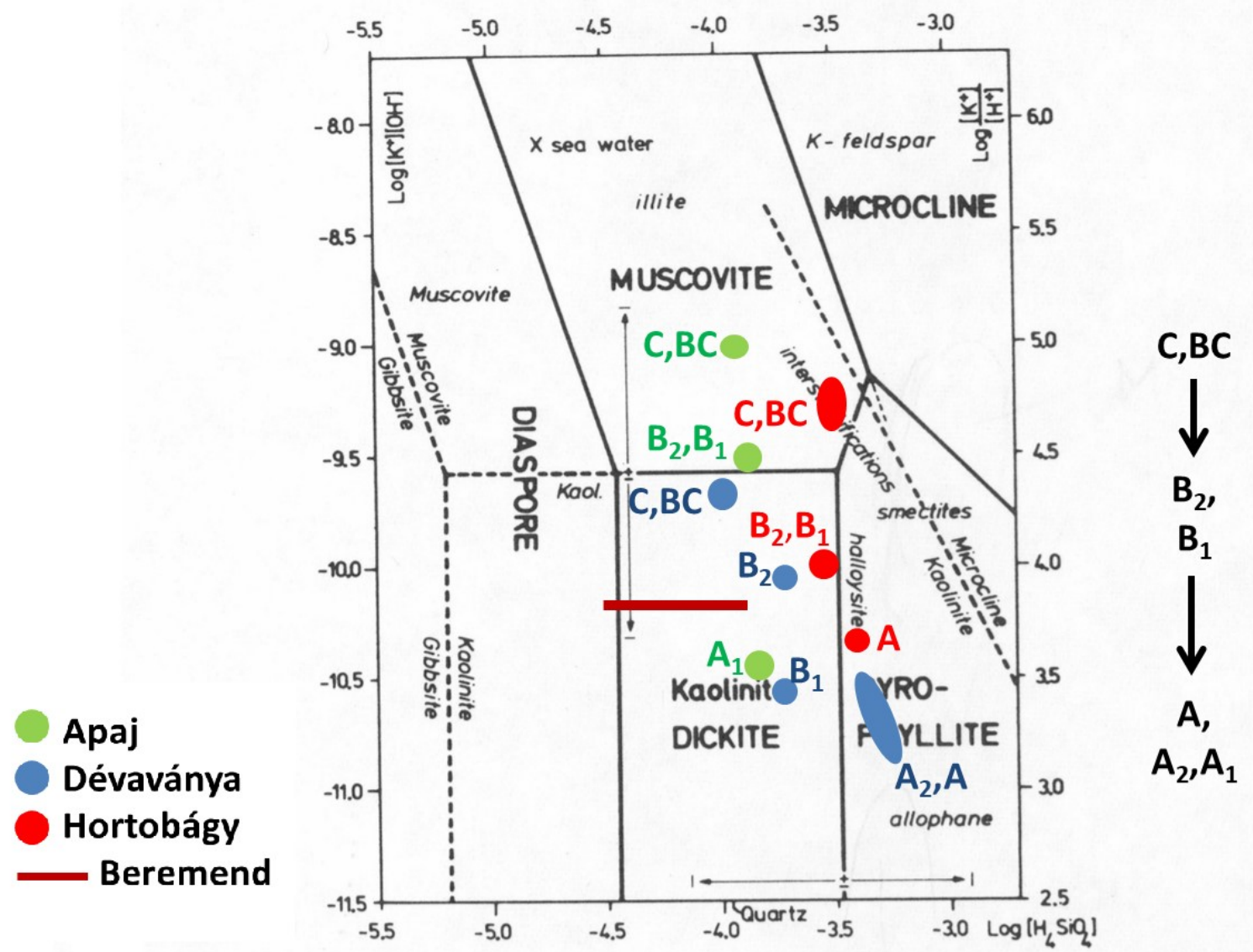

1. ábra: Ásványok stabilitási viszonyai a $\mathrm{K}_{2} \mathrm{O}-\mathrm{Al}_{2} \mathrm{O}_{3}-\mathrm{SiO}_{2}-\mathrm{H}_{2} \mathrm{O}$ rendszerben, $25^{\circ} \mathrm{C}$-on, $\log \left(\left[\mathrm{K}^{+}\right] /\left[\mathrm{H}^{+}\right]\right)-\log \left[\mathrm{H}_{4} \mathrm{SiO}_{4}\right]$ diagram (Lippmann, 1982). $\mathrm{Al}_{2} \mathrm{O}_{3}$ immobilis komponens.

Jelmagyarázat: lásd a szövegben.

Alkalmazások:

1. Alföldi szikes talajok telítési kivonatában mért ion-aktivitás értékek (Szendrei, 1981). Az egyes lelőhelyekre vonatkozó pontok közül a diagramon a felső pont a $C$ és $B C$ szint összevonva, a középső a $B_{1}$ és $B_{2}$ szint összevonva és az alsó az $A_{1}$ és $A_{2}$ szint összevonva, illetve az A szint. A dévaványai szelvény esetében külön ábrázoltam a $B_{1}$ és $B_{2}$ szinteket.

2. Beremendi vörös agyagok stabilitása.

Figure 1: Stability relations of minerals in the system $\mathrm{K}_{2} \mathrm{O}-\mathrm{Al}_{2} \mathrm{O}_{3}-\mathrm{SiO}_{2}-\mathrm{H}_{2} \mathrm{O}$, at $25{ }^{\circ} \mathrm{C}$, diagram $\log \left(\left[\mathrm{K}^{+}\right] /\left[\mathrm{H}^{+}\right]\right)-\log \left[\mathrm{H}_{4} \mathrm{SiO}_{4}\right]$ (Lippmann, 1982). $\mathrm{Al}_{2} \mathrm{O}_{3}$ immobile component. Legend: see in the text.

Applications: 
1. Activity values measured in saturation extract of salt affected soils of the Great Hungarian Plain (Szendrei, 1981). Different colours refer to different localities. At each locality the upper point refers to soil horizons $\mathrm{C}$ and $\mathrm{BC}$, the middle point to horizons $\mathrm{B}_{1}$ and $\mathrm{B}_{2}$ and the lower point to horizons $\mathrm{A}_{1}$ and $\mathrm{A}_{2}$ or horizon $\mathrm{A}$. At locality Dévaványa the horizons $\mathrm{B}_{1}$ and $\mathrm{B}_{2}$ is shown separately.

2. Stability of red clays at Beremend (Villány Mts.).

A Zebecke-2. fúrás a Dunántúli-középhegységi egységnek a nyugati felére esik, ahol az alaphegység már pannóniai és középső-miocén üledékek alatt lesüllyedve alkotja a Zalaimedence aljzatát. Itt több feltolódással bonyolult szerkezetü, ismétlődő mezozoos-paleogén rétegsor alakult ki. A dickit a 20. magban, 3880-3881,5 m mélységben jelenik meg, szintén kaolinit és kevés illit társaságában. A bezáró kőzet felső-triász breccsás fődolomit, amely kalcitereket és piritet tartalmaz. A mikroszkópi vizsgálat (Ravaszné Baranyai Livia) feltehetően kaolinites ér-kitöltést mutatott ki. A dickitet és a kaolinitet a röntgen-felvételen éles $h \mathrm{kl}$ reflexióik alapján lehetett azonosítani. A termikus vizsgálat is nakritot vagy dickitet mutatott ki (Földvári Mária). A nagy hőmérséklet és az esetlegesen ezzel összefüggő hidrotermás hatás a nagy felszín alatti mélységnek köszönhetö.

A harmadik hely, ahol dickitet lehetett kimutatni, az ország keleti felében mélyült Doboz-I. mélyfúrás volt. Itt a mezoos alaphegység a Békési-süllyedék aljzatát alkotja, és a Villányi nagyszerkezeti egységhez tartozik. A nagyszerkezeti egységen belüli jellegzetes mezozoos rétegsorokat Császár Géza (2005, 83. ábra, p. 244) hasonlította össze. Eszerint a dobozi rétegsor mind a felszínen lévő villányi, mind a bihari rétegsorra hasonlít. Mindhárom helyen a jura lepusztult felszínére kaolinos mállási kéreg települ, amelyet alsó-kréta tengeri rétegek fednek le. Ebben a dobozi rétegsor kivételével bauxit is megjelenik. Bauxitot találunk hasonló települési helyzetben a közeli Biharugra Bihu-I. sz. mélyfúrásban is (Viczián, 2015). Mind a kaolin-ásványok, mind a bauxit-ásványok különböző módon átalakultak a diagenezis erőssége függvényében.

A Doboz-I. fúrásban a 2. magban, 4271,1 m mélységben levő jura mészkő tartalmaz dickitet kaolinit, sudoit, tosudit és illit társaságában. Itt az agyag hasadékot tölt ki a mészkőben, ennek $<2 \mu \mathrm{m}$ frakciójáról készült a röntgenvizsgálat. A dickitet $h k l$-reflexiói alapján, a sudoitot és tosuditot $00 l$ bázisreflexióik sorozata alapján lehetett azonosítani. A dickit és többi diagenetikus ásvány képződéséhez itt is a nagy mélységgel járó magas hőmérséklet és a kőzet tektonikus töredezettsége járulhatott hozzá.

Az üledékes kőzettani megfigyeléseket összegezve azt tapasztaljuk, hogy a dickit felszíni körülmények között nem keletkezik, hanem a mély diagenezis és az anchimetamorfózis (igen kisfokú metamorfózis) jellegzetes ásványa (Aihara, 1993). Ilyen értelemben sok hasonlóságot mutat az anchimetamorf módon keletkezett kálium-tartalmú fehér csillám (,illit”, „szericit”) keletkezésével (Lanson et al., 2002).

A stabilitás elméleti számítására rátérve azonos kémiai összetételü kristálymódosulatok közül azt tekintjük stabilabbnak, amelyiknek a $\Delta \mathrm{G}_{\mathrm{f}, 298}^{\mathrm{f}}$ Gibbs-féle képződési szabadenergiája $\left(\mathrm{kJ} \mathrm{mol}^{-1}\right)$ abszolút értékben a legnagyobb. A kaolin-csoport ásványaira a számított értékeket az 1. táblázat tartalmazza (itt azonos kémiai összetételnek tekintjük, ha csak a víztartalom változó). Az 1. táblázatban aláhúzással jelöltük a stabil fázis adatát.

Látható, hogy a kaolinit és a dickit adatai között nagyon kicsi a különbség, és az is a legtöbbször hibahatáron belül van, függetlenül a mérés módszerétől. A mért adatok 298 K-ra vonatkoznak, ami megfelel $25^{\circ} \mathrm{C}$-nak. Zotov et al. (1998) megjegyzik, hogy nagyobb hőmérsékleten, $25-300{ }^{\circ} \mathrm{C}$ között végig a dickit a stabilabb, mint a kaolinit, de nagyobb hőmérsékleten a különbség kisebb lesz. Nemecz Ernő (2006) könyvében is megtaláljuk a 6. táblázatban a legfontosabb ásványok Gibbs-féle képződési szabadenergia adatait. Eszerint legtöbbször a kaolinit a stabil fázis, a dickit metastabil, még inkább metastabil a halloysit, de a kaolinit és dickit adatai nagyon közel állnak egymáshoz. 
A stabilitásra lehet következtetni ab initio rácsenergia-számításokkal is (2. táblázat). Lippmann is ennek alapján tekintette a dickitet stabilabbnak a kaolinitnél. De itt sem egyértelmủek az eredmények egyik vagy másik ásvány javára. Benco et al. (2001) szerint a dickit valamivel nagyobb rácsenergiájú, mint a kaolinit. Sato et al. (2004) szerint a rácsenergiák hibahatáron belül egyeznek a dickit, nakrit és a kaolinit két különböző típusú rácshibás változatai között, a kaolinit rácsenergiája csak egy harmadik típusú rácshiba esetén kisebb határozottan.

\section{1. táblázat: A kaolin-csoport ásványainak Gibbs-féle $\Delta \mathrm{G}_{\mathrm{f}, 298}^{\mathrm{r}}$ képződési szabadenergia $\left(\mathrm{kJ} \mathrm{mol}^{-1}\right)$ értékei.}

Table 1: Gibbs energies of formation $\Delta \mathrm{G}_{\mathrm{f}, 298}^{\mathrm{o}}\left(\mathrm{kJ} \mathrm{mol}^{-1}\right)$ for the minerals of kaolin group.Halloysit.

\begin{tabular}{|l|l|l|l|l|}
\hline & Kaolinit & \multicolumn{1}{|c|}{ Dickit } & \multicolumn{1}{|c|}{ Hivatkozás } & \multicolumn{1}{|c|}{ Módszer } \\
\hline & $-3799,4 \pm 2,7$ & $-3796,3 \pm 2,7$ & $\begin{array}{l}\text { Hemingway \& } \\
\text { Robie, 1977; } \\
\text { Lippmann, 1979 }\end{array}$ & $\begin{array}{l}\text { oldékonyság- } \\
\text { mérés }\end{array}$ \\
\hline$-3776,8 \pm 5,8$ & $-3799,4 \pm 6,4$ & $-3785,1 \pm 5,6$ & $\begin{array}{l}\text { Ligny de \& } \\
\text { Navrotsky, 1999 }\end{array}$ & $\begin{array}{l}\text { olvadékban oldás, } \\
\text { kalorimetria }\end{array}$ \\
\hline & $-3793,9 \pm 4,1$ & $-3785,1 \pm 5,6$ & Fialips et al., 2001 & $\begin{array}{l}\text { olvadékban oldás, } \\
\text { kalorimetria }\end{array}$ \\
\hline & & $-3777,5 \pm 4,8$ & Fialips et al., 2003 & $\begin{array}{l}\text { olvadékban oldás, } \\
\text { kalorimetria }\end{array}$ \\
\hline & $-3796,8 \pm 1,3$ & $-3798,1 \pm 1,7$ & Zotov et al., 1998 & $\begin{array}{l}\text { oldékonyság- } \\
\text { mérés }\end{array}$ \\
\hline & $-3797,7$ & & Devidal et al., 1996 & $\begin{array}{l}\text { oldékonyság- } \\
\text { mérés }\end{array}$ \\
\hline & $-3796 \pm 10,0$ & $-3805,0 \pm 10,0$ & Kiseleva et al., 2011 & $\begin{array}{l}\text { olvadékban oldás, } \\
\text { kalorimetria }\end{array}$ \\
\hline$-3759,0$ & $-3777,6$ & $-3774,6$ & Nemecz, 2006 & \\
\hline
\end{tabular}

2. táblázat: A kaolin-csoport ásványainak ab initio számításokkal kapott rácsenergia értékei $\left(\mathrm{kJmol}^{-1}\right)$.

Table 2: Lattice energy values $\left(\mathrm{kJ} \mathrm{mol}^{-1}\right)$ for the minerals of kaolin group.

\begin{tabular}{|l|c|c|c|l|}
\hline & Kaolinit & Dickit & Nakrit & \multicolumn{1}{|c|}{ Hivatkozás } \\
\hline $\begin{array}{l}\text { U vs. rétegközi távolság } \\
\text { meredeksége }\left(\mathrm{e}^{2} / \AA / \AA\right)\end{array}$ & 0,161 & 0,200 & 0,183 & Giese, 1973 \\
\hline függőleges $\mathrm{E}_{\text {tot }}(\mathrm{kJ} / \mathrm{mol})$ & $+26,0$ & $+27,6$ & & Benco et al., 2001 \\
\hline $\begin{array}{l}\Delta \mathrm{E}=\mathrm{E} \\
-\mathrm{E}(\text { egyedüli kaolinit-réteg) } \\
\left(\mathrm{kJ} \mathrm{mol}^{-1}\right)\end{array}$ & $\begin{array}{l}-1,858(\mathrm{~B}) \\
-2,050(\mathrm{C}) \\
-1,671(\mathrm{~A})\end{array}$ & $-1,980$ & $-2,084$ & Sato et al., 2004 \\
\hline
\end{tabular}


Lippmann (1982, p. 477) hangoztatta, hogy magasabb hőmérsékleten a dickit nem azért jelenik meg, mert az a csoporton belül a magas hömérsékleten stabil fázis, hiszen már közönséges hőmérsékleten is az volna. A megemelkedett hőmérséklet és a bőséges vízcirkuláció csak kinetikai hatások, amelyek az átalakulási reakció lefolyását elősegítik a különben is - stabil dickit irányában: „, The mode of occurrence of dickite can merely be explained by recognizing that temperature or rather thermal activation, promotes the formation of the most stable phase." Újabb szerzők a földtani elöfordulások részletes vizsgálata alapján ebböl a kinetikai tényezők hatását ma is elfogadják, de óvatosabbak annak kimondásában, hogy a kaolinit-dickit-nakrit reakció irányát a stabilitási különbségek szabják-e meg, vagy éppen fordítva, a stabil kaolinitből keletkezik a diagenezis során metastabil dickit és nakrit (Ligny de \& Navrotsky, 1999). Egy újabb mérés megint inkább a dickit nagyobb stabilitását hozta ki a kaolinittel szemben, bár majdnem a hibahatáron belül lévő különbséggel (Kiseleva et al., 2011). Ezért a kőzettani magyarázatok más szempontokat is keresnek, mint a termodinamikai stabilitást. Fontosnak tartják, hogy a kristályosodást befolyásoló tényezők között a hőmérsékleten kívül figyelembe kell venni még más tényezőket, így a nyomást és az oldódáskiválás körülményeit is (Ruiz Cruz, 2007; Cuadros et al., 2014). A dickit keletkezésére vonatkozó termodinamikai adatok és a földtani megfigyelések között ma még fennálló ellentmondásról egy újabb tekintélyes összefoglaló munka azt mondja, hogy az egy eddig még meg nem oldott paradoxon: „, a paradox that has so far not been resolved” (Wilson, 2013, p. $61)$.

\section{Közel izokémikus metastabil - kevésbé metastabil átmenet: szabályos kevert rétegü corrensit képződése a gerecsei alsó-krétában}

Míg a dickit és kaolinit keletkezése esetében az volt a kérdés, hogy két közel egyformán stabil fázis közül melyik az igazán stabilnak tekinthető, addig a különböző mértékben metastabil, három-, illetve négyrétegü komponensekből álló kevert szerkezetek esetében a termikus aktiváció azt érheti el, hogy lehetséges fázisok közül a kevésbé metastabil keletkezik. Erre példa a szabályos kevert rétegü corrensit képződése a gerecsei alsó-krétában.

A lelőhely a Bersek-hegy szelvénye volt. Ez a szelvény a valangini-barrémi (alsó-apti) korú Berseki Márga és Lábatlani Homokkő Formációkat tárja fel. Ezek mélytengeri körülmények között ülepedtek le, és nagy arányban bázisos vulkáni kőzettörmeléket, illetve agyagos kötőanyagot tartalmaznak. Mind a két formációra jellemző a $\mathrm{Cr}$-gazdag spinell, amely a bázisos-ultrabázisos lehordási területek indikátora. A vizsgálatokat mindkét formációból az agyagosabb-márgásabb mintákon végeztük (Viczián \& Kovács-Pálffy, 1997). Az agyagfrakcióban rendszeresen nem-ideális, corrensit-szerü szabályosan kevert rétegü ásványokat találtunk, amelyeknél azonban mindig megvolt 29 Á-nél az első bázisreflexió, és ennek szabályos sorozata is. Az etilén-glikolos és hevítéses kezelésekkel kimutattuk, hogy a kevert szerkezetet különböző arányban trioktaéderes klorit, szmektit és vermikulit rétegek építik fel. Ezekben a komponensek arányától függően különböző mértékü duzzadást mutattunk ki, amelynek mértéke alulról felfelé 10-20\%-ról 30-40\%-ra nött.

Megjegyzendő, hogy ez a szabályos kevert szerkezet már két szomszédos, hasonlóan nagy mennyiségü bázisos vulkáni üledékanyagot tartalmazó képződményben, a késő-apti - koraalbai Köszörükőbányai Konglomerátum Tagozatban és a Tatabányai-medencében fúrással feltárt albai Vértessomlói Aleurolit Formációban már nem volt kimutatható, helyette ugyanezeknek a komponenseknek a szabálytalan rétegsorrendü kevert szerkezeteit találjuk.

A corrensit a definíció szerint trioktaéderes klorit és trioktaéderes szmektit vagy vermikulit szabályos kevert szerkezete (Lippmann, 1954; Bailey, 1982). Hozzávetőleges képződési 
tartományát Lippmann (1981) a $\log \left[\mathrm{Mg}^{2+}\right]\left[\mathrm{OH}^{-}\right]^{2}-\log \left[\mathrm{H}_{4} \mathrm{SiO}_{4}\right]$ diagramon a klinoklor stabilitási mezejében helyezte el, egyik oldalon az „üledékes kloritok”, másik oldalon a szaponit és a montmorillonit képződési tartománya között (2. ábra). Bár nincsenek feltüntetve, de bizonyára ide esnének a szabálytalan rétegsorrendü klorit/szmektit és klorit/vermikulit kevert szerkezetek is.

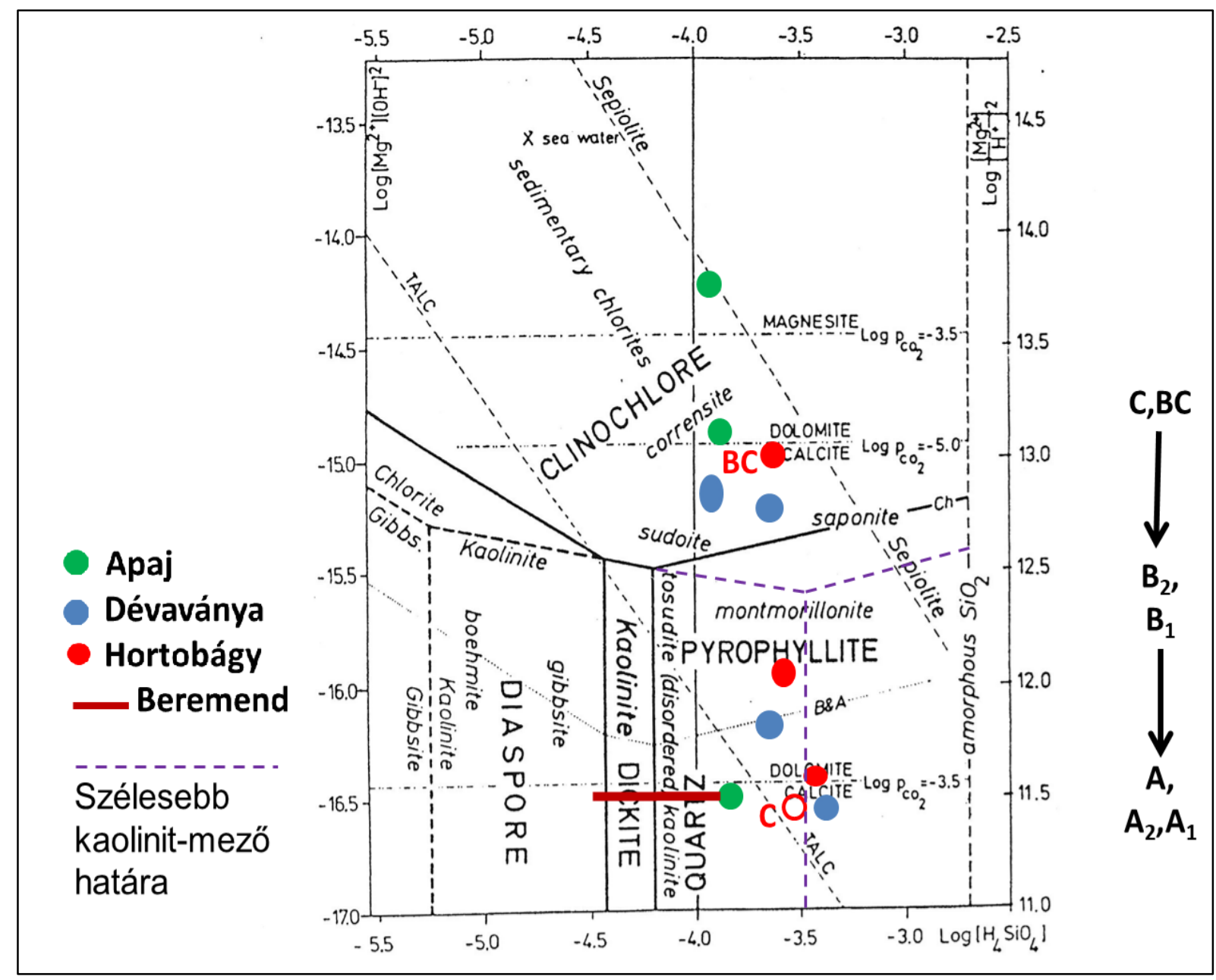

2. ábra: Ásványok stabilitási viszonyai a $\mathrm{MgO}-\mathrm{Al}_{2} \mathrm{O}_{3}-\mathrm{SiO}_{2}-\mathrm{H}_{2} \mathrm{O}$ rendszerben, $25^{\circ} \mathrm{C}$-on, $\log \left(\left[\mathrm{Mg}^{2+}\right] /\left[\mathrm{H}^{+}\right]^{2}\right)-\log \left[\mathrm{H}_{4} \mathrm{SiO}_{4}\right]$ diagram (Lippmann, 1981). $\mathrm{Al}_{2} \mathrm{O}_{3}$ immobilis komponens. Jelmagyarázat: lásd a szövegben.

Alkalmazások:

1. Alföldi szikes talajok telítési kivonatában mért ion-aktivitás értékek (Szendrei, 1981). Szintek jelölése mint az 1. ábrán. A hortobágyi szelvény esetében a felső pont csak a BC szintre vonatkozik, a C szint értékét üres körrel külön tüntettem fel.

2. Beremendi vörös agyagok stabilitása.

Figure 2: Stability relations of minerals in the system $\mathrm{MgO}-\mathrm{Al}_{2} \mathrm{O}_{3}-\mathrm{SiO}_{2}-\mathrm{H}_{2} \mathrm{O}$, at $25{ }^{\circ} \mathrm{C}$, diagram $\log \left(\left[\mathrm{Mg}^{2+}\right] /\left[\mathrm{H}^{+}\right]^{2}\right)-\log \left[\mathrm{H}_{4} \mathrm{SiO}_{4}\right]$ (Lippmann, 1981). $\mathrm{Al}_{2} \mathrm{O}_{3}$ immobile component. Legend: see in the text.

Applications:

1. Activity values measured in saturation extract of salt affected soils of the Great Hungarian Plain (Szendrei, 1981). Soil horizons are shown as in Figure 1. In the case of Hortobágy locality the upper point refers only to the horizon $\mathrm{BC}$, the horizon $\mathrm{C}$ is shown by an empty circle.

2. Stability of red clays at Beremend (Villány Mts.). 
Arra nézve, hogy ezek közül melyik a kevésbé metastabil, nincs kísérleti adat, de a földtani megfigyelések szerint a szabálytalan klorit/szmetit/vermikulit kevert szerkezetek elterjedten képződnek bázisos vulkáni anyagból normális hőmérsékleten, míg a corrensit hasonló kiindulási anyagból csak nagyobb hőmérsékleten, diagenetikus körülmények között keletkezik. Kübler (1984) zónabeosztása szerint a corrensit vulkáni törmelékes kőzetekben a „közepes diagenezis" zónájára jellemző, az agyagásványok közül a (trioktaéderes) szmektiteket váltja fel. A corrensit diagenetikus megjelenésére vonatkozólag az irodalomban található hőmérsékleti határok durván a $100-200{ }^{\circ} \mathrm{C}$ közé esnek (Viczián \& Kovács-Pálffy, 1997). Eszerint itt egy termikus aktiváció váltotta ki, hogy a nagyon instabil véletlenszerü klorit/szmektit/vermikulit kevert szerkezetek helyett az azokkal közelítőleg azonos kémiai összetételü, de azoknál bizonyára stabilabb, szabályosabb szerkezetü fázis, a corrensit keletkezett.

A Bersek-hegyi alsó-kréta rétegsor átalakultságára kapott eredmény jó összhangban van az alatta következő jura rétegsorban az illit/szmektit átalakultságára kapott összefüggésekkel (Viczián, 1995, 10. ábra), ami érdekes földtani következtetéseket tesz lehetővé. A jura kőzetek átalakultsága a Gerecsében rendszeresen nagyobb, mint a Bakonyban, sőt még a nagylengyeli juráét is meghaladja, csak a Zalai-medence nagymélységű aljzatának jura képződményei erősebben átalakultak. A Bersek-hegyi alsó-krétában az illit/szmektit d(001/001) értékei jól illeszkednek a hivatkozott ábrán a Gerecse-hegységi jurára meghúzott trendvonal folytatásába, de a rétegtanilag felette települö Köszörükö-bányában és a Vértessomlói Aleurolitban ez az átalakultság már nem látszik. Lehetséges, hogy ez az átalakultság a normális települési mélységgel is magyarázható, ami a nagy lepusztulás miatt nehezen rekonstruálható. De felmerül annak a lehetősége is, hogy a hegység nagy részét az alsó-krétában, a Bersek-hegyi szelvény leülepedése után bekövetkező hőhatás érte.

\section{Egyensúlyi diagramok kémiai változókkal}

A Lippmann által szerkesztett egyensúlyi diagramokon a vízszintes tengelyen a kovasav aktivitása van, a függőleges tengelyen pedig egy-egy kiválasztott kation, $\mathrm{K}^{+}, \mathrm{Na}^{+}$vagy $\mathrm{Mg}^{2+}$ és a $\mathrm{H}^{+}$ion aktivitásának a hányadosa (1-3. ábra). Itt a külső tényezők közül a hőmérséklet $25^{\circ} \mathrm{C}$ és a nyomás $1 \mathrm{~atm}$, ezek nem szerepelnek mint változók. Mivel a hőmérséklet és a nyomás a normális felszíni körülményeknek felelnek meg, az ilyen diagramok különösen alkalmasak a talajképződés és a kémiai üledékképződés viszonyainak modellezésére, ahol a fó ásványképző tényező a vizes oldatok kémiai összetételének változása.

Lippmann ezeket a diagramokat elöször 1979-ben és 1981-ben publikálta. Később annyit változtatott rajtuk, hogy a kaolinit stabilitási mezeje a nagyobb kovasav-tartalmak felé szélesebb lett. $\mathrm{A}_{2} \mathrm{O}-\mathrm{Al}_{2} \mathrm{O}_{3}-\mathrm{SiO}_{2}-\mathrm{H}_{2} \mathrm{O}$ rendszerre vonatkozó javított diagram 1982-ben jelent meg (1. ábra). A Na $\mathrm{Na}_{2} \mathrm{O}-\mathrm{Al}_{2} \mathrm{O}_{3}-\mathrm{SiO}_{2}-\mathrm{H}_{2} \mathrm{O}$ rendszerre vonatkozó diagramot elkészítette kéziratban, de azt csak később, az ő engedélyével Viczián (1992) jelentette meg (3. ábra). Tudomásom szerint a $\mathrm{MgO}-\mathrm{Al}_{2} \mathrm{O}_{3}-\mathrm{SiO}_{2}-\mathrm{H}_{2} \mathrm{O}$ rendszerre vonatkozó diagram javított változatát nem is készítette el, de azt értelemszerüen módosítani lehet a másik két diagram alapján. Ebben a dolgozatban így használom ezt a diagramot (2. ábra).

A diagramokon használt jelölésekkel kapcsolatban a következőket kell figyelembe venni:

[ ]-ben: az oldott komponensek aktivitása,

NAGYBETÜK: stabil ásványok (pl. DIASZPOR, DICKIT stb.),

Dölt betük nagy kezdöbetüvel: metastabil ásványok, amelyek metastabil egyensúlyokban vesznek részt (pl. Kaolinit, Gibbsit, stb.), dölt betük kis kezdöbetüvel: instabil ásványok (pl. szmektit, illit, stb.). 
A Kaolinit majdnem olyan stabil, mint a DICKIT. Alul a $\log \left[\mathrm{H}_{4} \mathrm{SiO}_{4}\right]$ tengelyen van feltüntetve a kvarc stabilitási határa, amelytől jobbra a kvarc is stabil a rendszerben. A diagram jobb szélénél nagyobb kovasav-koncentrációk mellett már amorf kovasav válik ki. Folytonos vonalak: stabil fázishatárok, szaggatott vékony vonalak: metastabil fázishatárok.

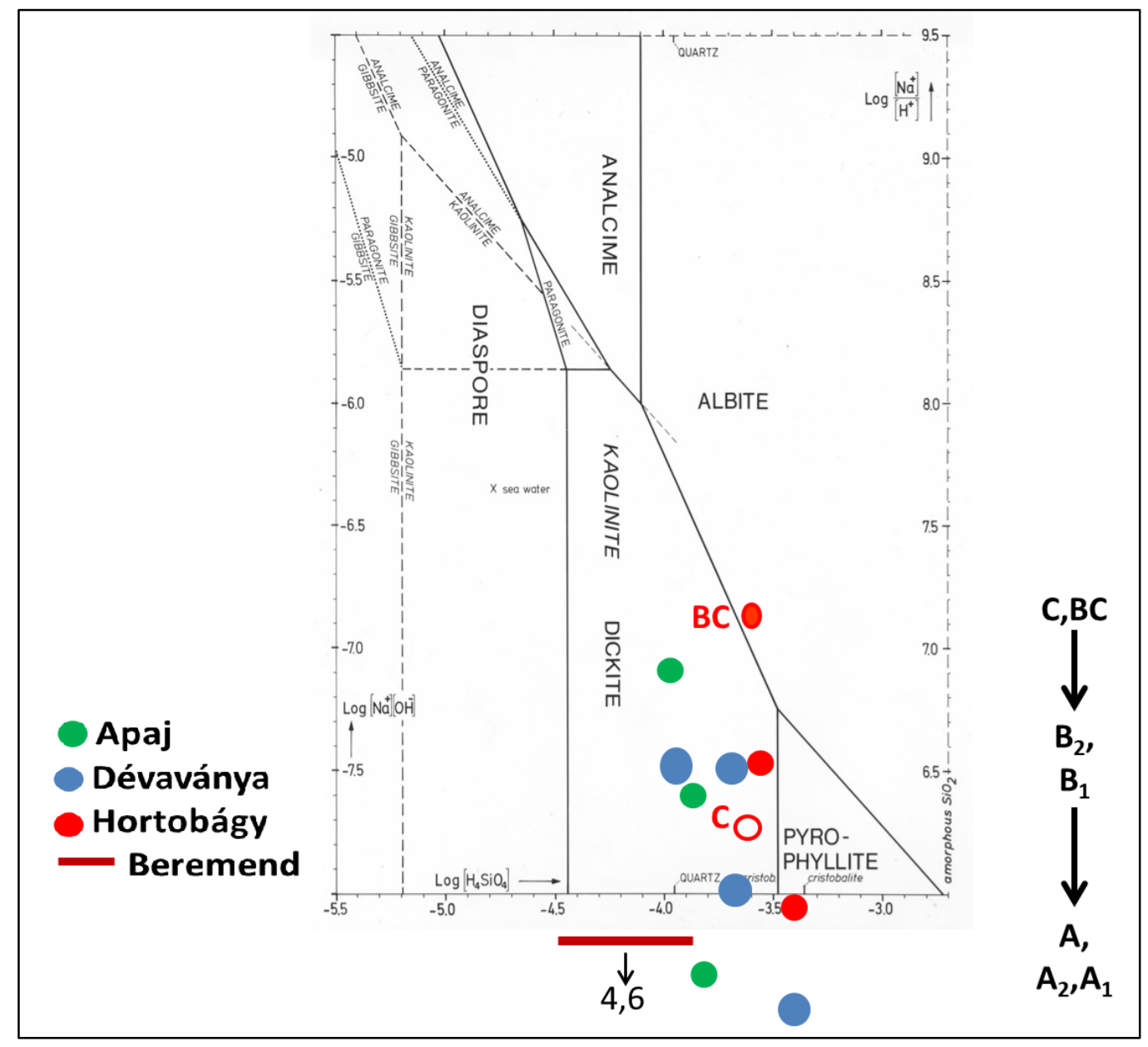

3. ábra: Ásványok stabilitási viszonyai a $\mathrm{Na}_{2} \mathrm{O}-\mathrm{Al}_{2} \mathrm{O}_{3}-\mathrm{SiO}_{2}-\mathrm{H}_{2} \mathrm{O}$ rendszerben, $25^{\circ} \mathrm{C}$-on, $\log \left(\left[\mathrm{Na}^{+}\right] /\left[\mathrm{H}^{+}\right]\right)-\log \left[\mathrm{H}_{4} \mathrm{SiO}_{4}\right]$ diagram (Viczián, 1992, Lippmann nyomán). $\mathrm{Al}_{2} \mathrm{O}_{3}$ immobilis komponens.

Jelmagyarázat: lásd a szövegben.

Alkalmazások:

1. Alföldi szikes talajok telítési kivonatában mért ion-aktivitás értékek (Szendrei, 1981). Szintek jelölése mint az 1. ábrán. A hortobágyi szelvény esetében a felső pont csak a BC szintre vonatkozik, a C szint értékét üres körrel külön tüntettem fel.

2. Beremendi vörös agyagok stabilitása.

Figure 3: Stability relations of minerals in the system $\mathrm{Na}_{2} \mathrm{O}-\mathrm{Al}_{2} \mathrm{O}_{3}-\mathrm{SiO}_{2}-\mathrm{H}_{2} \mathrm{O}$, at $25{ }^{\circ} \mathrm{C}$, diagram $\log \left(\left[\mathrm{Na}^{+}\right] /\left[\mathrm{H}^{+}\right]\right)-\log \left[\mathrm{H}_{4} \mathrm{SiO}_{4}\right]$ (Lippmann, published by Viczián 1992). $\mathrm{Al}_{2} \mathrm{O}_{3}$ immobile component.

Legend: see in the text. Applications:

1. Activity values measured in saturation extract of salt affected soils of the Great Hungarian Plain (Szendrei, 1981). Soil horizons are shown as in Fig. 1. In the case of Hortobágy locality the upper point refers only to the horizon $\mathrm{BC}$, the horizon $\mathrm{C}$ is shown by an empty circle.

2. Stability of red clays at Beremend (Villány Mts.) 


\section{Ásványok egyensúlyi viszonyai alföldi szikes talajokban (Szendrei Géza nyomán)}

Szendrei Géza volt az első, aki a stabilitási diagramokat ásványképződés magyarázatára használta hazánkban (Szendrei, 1981, 1985). Három jellegzetes alföldi szikes talaj-szelvényben vizsgálta a stabilitási viszonyokat. A szikes talajokról írt utolsó, összefoglaló munkájában még egyszer visszatért erre a témára (Szendrei, 2017). A három talajszelvény a következő volt:

- szoloncsákos réti szolonyec, Apaj;

- szologyos, közepes réti szolonyec, Dévaványa és

- szologyos, kérges réti szolonyec, Hortobágy.

A szoloncsák típusú szikes talajok felszínén megjelenik a sziksó kivirágzás. A szology talajokban porszerü amorf kovasav keletkezik, amelynek maximuma a felszínhez közel, az A szintben van. A diagramokban való ábrázolásra az adott lehetőséget, hogy Darab Katalin és munkatársai kísérletileg meghatározták az ionok aktivitását ezekből a talajokból készített telítési kivonatokban. Az aktivitási értékeket, valamint a pH értékeit Szendrei (1981) táblázatban közölte. Az adatokat az akkor ismert többféle stabilitási diagramban grafikusan ábrázolta, ezek között voltak Lippmann 1979-es diagramjai is. Az ábrázolásban nem tett különbséget az egyes lelőhelyek és az egyes talajszintek között, így a következtetései is - egykét kivételtől eltekintve - csak a talajok egészére vonatkoztak.

Szendrei Géza (1981) megállapításai szerint abban minden diagram hasonló eredményt hozott, hogy az elsődlegesnek tartott ásványok közül sem az albit, sem a káliföldpát, sem a muszkovit nem stabilak már a talajban, és ezek oldódására lehet számítani. Bár a kloritot nem számolta az elsődleges ásványok közé, megállapította, hogy az a minták egy részénél stabil fázisnak tekinthető. A másodlagosnak tekintett agyagásványok között már nagyobb bizonytalanságot tapasztalt, ami részben az akkor ismert diagramok egymás közötti eltéréseinek és hibáinak tulajdonítható. Helgeson et al. (1969) diagramjai közül a Na-os diagram szerint Namontmorillonit lenne a stabil fázis. De ez valószínúleg részben a hibás határmegvonás következménye, ezen kívül a Na-montmorillonit szerepeltetése már elvileg is hibás, lévén a montmorillonit metastabil fázis. A K-os diagramon viszont minden minta a kaolinit stabilitási mezejébe esett, a kaolinit mező felső határának túl tág megvonása miatt. Lippmann diagramjain viszont a kaolinit-mező akkor még túl szük megvonása miatt a minták nagy része a pirofillit mezőbe esett. Szendrei Géza utalt arra, hogy a pirofillit helyett a valóságban inkább montmorillonit keletkezik, de a későbbi vizsgálatok szerint ez is kétséges.

Az 1985-ben megjelent publikációban, amelyben csak a hortobágyi szelvény adatait tárgyalja, már Lippmann 1982-es, javított diagramját vette figyelembe a K-os rendszernél. A 3. táblázatban közölt összesítés szerint így a legfőbb stabil ásvány a kaolinit lett, emellett a Mgos rendszer diagramja alapján a klorit és itt a szük kaolinit mező miatt megmaradt a pirofillit is. A 2017-es összefoglalás táblázatban közli az összes diagram kiértékelésével kapott eredményeket, és már bizonyos különbséget is tesz az egyes talajszintek között. Ezeket összesítve azt írja, hogy „a kaolinit, a klorit és a montmorillonit fordult elő stabil ásványként” (p. 93).

Az eddigi eredmények ellenőrzése és továbbfejlesztése céljából a javított Lippmann-féle diagramokra felvittem a kísérleti aktivitási értékeket lelöhely és talajszint szerint megkülönböztetve (1-3. ábra), csak az ábrázolás miatt tettem kisebb összevonásokat a talajszintek között.

Az ábrákból látszik, hogy a három lelőhely és a két talajtípus jól elkülönül egymástól. Az apaji szoloncsák kisebb kovasav-értékeknél helyezkedik el, mint a hortobágyi szologyos talaj, de kovasav-tartalmuk az egész szelvényben közel állandó. A dévaványai szologyos talaj viszont mintegy átmenetet képez a kettő között, C és BC szintjében az apaji szoloncsákra hasonlít, de 
az A szintben már a másik, hortobágyi szologyos talajjal tartalmaz csaknem azonos, sőt azt meg is haladó kovasav-tartalmú talajoldatot. $\mathrm{A} \mathrm{B}_{1}$ és $\mathrm{B}_{2}$ szintekben átmeneti értéket mutat. Hasonló eloszlást találtak Szabolcs \& Szendrei (1980) e két szelvény telítési kivonataiban talált összes, kolloidális és oldott kovasav tartalmakban is.

A kovasavval kapcsolatban fontos megjegyezni, hogy a kb. $\log \left[\mathrm{H}_{4} \mathrm{SiO}_{4}\right]=-4,0$ értéktöl kezdve a diagramokon a kvarc is stabil fázis, és ha a koncentráció ezt jelentősen meghaladja, a cristobalit, majd az amorf kovasav kiválása várható, együtt a megfelelő másik stabil ásvánnyal, pl. a kaolinittel vagy a pirofillittel. Ilyen értelemben jól elkülönülnek az amorf kovasav kiválásával jellemzett szologyos talajok és a szoloncsák talaj, amelyre viszont nem jellemző az amorf kovasav kiválása. Az apaji szoloncsák mindvégig ennek a határértéknek a közelében levő kovasavas oldatot tartalmaz, ami, úgy látszik, még nem tesz lehetővé jelentős kovasav kiválást. A két szologyos minta viszont, legalábbis a $\mathrm{B}_{1}$ és $\mathrm{B}_{2}$ szintektöl kezdve már a jelentősebb kovasav-koncentráció tartományába esik, ami meglátszik a kivált kovasav mennyiségén is. Erre Szendrei (1985) is utal a hortobágyi szelvénnyel kapcsolatban. Szabolcs \& Szendrei (1980) részletesen is foglalkoztak a két vizsgált szologyos szelvényben ennek a kovasavnak a kémiai és szerkezeti jellemzésével. A NaOH-ban és $\mathrm{KOH}$-ban kioldott kovasav mennyisége a talaj teljes anyagát tekintve 3-5\% lehet, de a hortobágyi szologyos szintben talált maximális érték majdnem eléri a 10\%-ot. Ennek a kioldható kovasavnak a feldúsulása a szologyos szintben az agyagfrakcióban még kifejezettebb. A szerzők szerint ez a kioldható kovasav a talaj amorf kovasav tartalmából származik. A szologyos szintben ehhez járulhat még a finomdiszperz kristályos kvarc oldódása is.

Szendrei (1981) 1. táblázatában vannak az ionaktivitás és $\mathrm{pH}$ adatok megadva. Az ionaktivitás adatok is mind $\mathrm{pNa}, \mathrm{pK}$ stb. alakban, így a hányadosuk logaritmus értéke a pH értékéből való egyszerü kivonással meghatározható a következő képlet szerint:

$$
\log \left(\left[\mathrm{K}^{+}\right] /\left(\left[\mathrm{H}^{+}\right]\right)=\log \left[\mathrm{K}^{+}\right]-\log \left[\mathrm{H}^{+}\right]=-\mathrm{pK}+\mathrm{pH}=\mathrm{pH}-\mathrm{pK} .\right.
$$

Minden esetben az ionaktivitás/ $\mathrm{H}^{+}$hányadosok szabályosan követik egymást a szintek szerint. A C és BC szintekben van a legnagyobb arány, és az A szintben a legkisebb. Ez alól csak egy kivétel van, a hortobágyi $\mathrm{C}$ szint (a $\mathrm{Na}$ és $\mathrm{Mg}$ ionokra nézve). De a $\mathrm{BC}$ szintre már itt is igaz, hogy ebben a legnagyobb az arány a szelvényen belül. Ugyanakkor külön-külön az ionaktivitás és a $\mathrm{pH}$ adatokra nincs ilyen egyértelmü összefüggés.

Ami a stabil ásványfázisokat illeti, a diagramok szerint a $\mathrm{C}$ és $\mathrm{BC}$ szintekben az ionaktivitás/ $\mathrm{H}^{+}$hányados még eléri a muszkovit és a klorit stabilitási mezejét, sőt a Na-os diagram szerint esetleg az albitét is. A szoloncsák mintánál a B és az A szintek egyértelmúen a kaolinit mezőbe esnek, a két szologyos mintánál viszont csak a B szintek, és az A szintek már a pirofillit mezőbe nyúlnak át, de az összetétel még mindig a kaolinit és pirofillit közötti határzónában marad. A pirofillit elméleti lehetősége itt mindig a szmektit megjelenésének lehetőségét jelenti. A diagramok szerint tehát a szikes talajokban a B és A szintekben a kaolinit és kisebb mértékben, a felszín közelében talán a pirofillit tekinthető stabil ásványnak, tehát a kaolinit és a szmektit keletkezése várható.

Ha ezeknek a talajoknak a tényleges ásványos összetételét tekintjük, az egyáltalán nem, vagy alig tükrözi ezt a várható összetételt. Szendrei Géza (1985, 1. ábra) közli a hortobágyi talaj $<0,5 \mu \mathrm{m}$ frakciójának ásványos összetételét. Az uralkodó agyagásványok illit, szmektit és illit/szmektit kevert szerkezet, a kaolinit nem éri el az 1\%-os mennyiséget, kvarc csak az A szintben mutatható ki kis mennyiségben. Ehhez még az A és B szintekben néhány \% amorf kovasavat vagy kristályos kvarcot is hozzászámíthatunk. Hasonló eredményre jutottak Kapoor et al. (1986) ásványtani vizsgálatai is szikes talajokon. Szendrei Géza (2017) összefoglaló adatai azt mutatják, hogy ez az ásványos összetétel alapvetően világviszonylatban is jellemző. 
Az ellentmondás feloldására Szendrei Géza (1981) és ehhez a cikkhez való hozzászólásában Darab Katalin is a kaolinit képződéséhez szükséges hosszú időtartamra utal. Valóban, az ásványos összetétel alapvetően átörököltnek látszik, mert az anyakőzetként számba jövő negyedidőszaki ártéri üledékek nagy része ilyen összetételü (Viczián, 2002), és ez az összetétel csak kevéssé változott meg a talajképződés ideje alatt a kémiai tényezők hatására.

Mégis a diagramból levonható következtetések magyarázhatják néhány \% amorf és finomkristályos kovasav, valamint kevés kaolinit jelenlétét. Már utaltunk rá, hogy a szologyos szelvények teljes egészében a kvarc stabilitási tartományába esnek. Ezen kívül várható a talajszelvények B és A szintjeiben a $\mathrm{C}$ és $\mathrm{BC}$ szintekben még stabil ásványok, a muszkovit, klorit és albit, vagy a már ott sem stabil K-földpát oldódása is. Ezek közül a földpátok oldódásakor vagy metastabil reakcióval közvetlenül kaolinit, vagy stabil reakcióval illit (illit/szmektit) keletkezhet, mindkét esetben kovasav egyidejü felszabadulása mellett. Az átöröklés következtében nagy mennyiségben jelen levő szmektit (és illit/szmektit) oldódása is lehetséges kaolinit és kovasav egyidejü kiválása mellett. Ez azokban a szintekben várható, ahol nem a pirofillit, hanem a kaolinit a stabil fázis, tehát az apaji szoloncsákos talaj $\mathrm{A}$ és $\mathrm{B}$ szintjeiben és a szologyos talajok B szintjeiben.

A másik jelentős ellentmondás a diagramokból leolvasható stabil ásványképződés és a reális ásványos összetétel között abban áll, hogy a szologyos szelvényekben az A szintekben már szmektitnek kellene képződni, ugyanakkor éppen ezekben a szintekben a szmektit tartalom erősen lecsökken. Szendrei Géza (2017) összefoglalása ennek magyarázatára két lehetséges folyamatot említ, az egyik a degradáció (a szmektit kioldódása), a másik az illuviáció (a szmektit bemosódása a mélyebb szintekre). Ezt a véleményt képviselik Kapoor et al. (1986) is. Egy harmadik lehetőség volna itt az ,átalakulás”-nak nevezett folyamat, azaz a szmektit illitesedése, de ez nem lehetséges a diagramok szerint, mert a muszkovit (illit) stabilitási mezeje messze esik az A szintekben mért oldat-összetételtől.

A javasolt folyamatok közül a kioldódás éppen amiatt nem lenne lehetséges, mert ebben a szintben a pirofillit a stabil ásvány, és ezért az azt helyettesítő szmektitnek is stabilnak kellene lenni (lásd 1-3. ábrák). Ha a szmektit a valóságban mégis kioldódik, amint azt a legtöbb leírás valószínüsíti, a legvalószínűbb magyarázat az lehet, hogy a valóságos szmektit metastabil fennmaradási tartománya nem esik egybe pontosan a pirofillit ideális stabilitási tartományával. Lehet, hogy az adott alacsony ionkoncentrációk mellett itt még inkább a szmektit oldódása és a kaolinit vagy a kaolin-csoporthoz közel álló, rendezetlen vagy amorf fázisok metastabil fennmaradása várható.

Az oldódáson kívül a legvalószínübb ok a felső szintekben keletkezett szmektit eltünésére a szmektit bemosódása a mélyebb szintekre (illuviáció). Szendrei (2017) megemlíti, hogy „a kiskunsági szoloncsák-szolonyec talajban Stefanovits \& Dombóvári (1986) is illuviációval értelmezte a szmektit eloszlását". Szerintük a bemosódást elősegíti, hogy a nátriumos közeg az agyagásványok diszpergálódását fokozza. Szendrei Géza az illuviációt mind a három szelvény esetében valószínüsíti, különösen a finom szemcsefrakciókban kimutatható ásványátrendeződések alapján. A bemosódást az apaji szoloncsákos szelvény esetében is feltételezi, amelynek legfelső rétege azonban nem is került a szmektit stabilitási mezejébe. Ennél csak az átörökölt szmektit tartalom bemosódásáról lehet szó.

Összefoglalva a vizsgált szikes talajokra kapott eredményeket megállapíthatjuk, hogy a diagramok jól jelzik az egész talajszelvény fejlődését, az elsődleges alkotórészek oldódását, továbbá a felső szintekben bekövetkező kovakiválást. A stabilnak jelzett kaolinit tényleges képződését a meglevő átörökölt ásványok rovására valószínüleg a kis reakciósebesség akadályozza. A szmektit jelenlétét az A szintekben valószínúleg az akadályozza, hogy az oldat összetétele a szmektit reális fennmaradási mezejét még nem érte el, csak az ideális pirofillit stabilitási mezejét. A mégis ott lévő szmektit viszont bemosódott az alsóbb szintekre. 


\section{Kaolinos vörös agyagok stabilitása karsztvízben a Villányi-hegységben}

Mint láttuk, a mai éghajlati viszonyok között nem keletkezik a hazai szikes talajokban jelentős mennyiségü kaolinit, akkor sem, ha az oldatok összetétele szerint ez volna a stabil fázis. Magyarországon az utolsó olyan időszak, amikor meleg, nedves, majdnem trópusi éghajlaton, hosszas talajképződési idő alatt kaolinitben gazdag talajok keletkeztek, a középső-pliocénben volt. Ezek egyik fontos előfordulása a Villányi-hegység karsztos felszínén található (Viczián, 2006-2007; Dezső et al., 2007b). A Beremendi-kőfejtőben karsztos üregeket, hasadékokat, barlangjáratokat tölt ki ilyen vörös agyag, amely az egykori felszínen levő talajtakaró bemosódásával került jelenlegi helyére. Ásványos összetételében a fó ásványok: rendezetlen kaolinit, kevert rétegü kaolinit/szmektit, szmektit. Esetenként gibbsit, kevés Ti-oxid, a Feoxidok közül több hematit, mint goethit és kevés kvarc is megjelenik. A földpát teljesen hiányzik. A kalcit mennyisége változó, néha mint a karsztvízből kivált cementáció jelentős, és arra utal, hogy ezeket az üregeket a bemosódás után sokáig karsztvíz tölthette ki. Ritkán elöfordulnak a karsztos üregekben kevésbé mállott vörös agyagok is, amelyekben a kaolinit tartalom kicsi, és a többi agyagásvány van nagyobb mennyiségben.

Felmerül a kérdés, milyen hatással lehetett az üregeket kitöltő karsztvíz a bemosott agyag összetételére, vajon alakíthatta-e tovább az ásványos összetételét? Ennek tisztázása érdekében igyekeztem adatokat gyüjteni a mai karsztvíz kémiai összetételéről, és ezeket a 3. táblázatban összesítettem. A Beremendi-kőfejtőben Dezső et al. (2007a) végeztek vízkémiai elemzéseket. Ezekben megtaláljuk a $\mathrm{pH}$ értékét és a $\mathrm{K}^{+}, \mathrm{Na}^{+}$és $\mathrm{Mg}^{2+}$ kationok mennyiségét. Az elemzéseket havonta megismételték, az itt szereplő adatok 4 mérés átlagai, de ezek egymás között nagyon kis mértékben tértek el. A sok vízelemzés közül azokat választottam ki, amelyek a szerzők véleménye szerint a legkevésbé keveredett, langyos, $20-25^{\circ} \mathrm{C}$ körüli karsztvizek. A kovasav tartalomra nézve Rappné Sík Stefánia két elemzését ismerjük, amelyeket Fülöp József publikált a monográfiájában (1966, p. 42 és p. 40). Ezek is hasonló, langyos vizek. Az egyik elemzés magából a Beremendi-kőfejtőből származik egy aknából, a másik a közeli Kistapolca forrásából, amely ugyanabból az alsó-középső-kréta Nagyharsányi Mészkőből ered, mint amelyet Beremenden is fejtenek.

3. táblázat: Karsztvizek elemzési adatai. Villányi-hegység, Budai-hegység $\left(\mathrm{g} \mathrm{dm}^{-3}\right)$.

Table 3: Analytical data for karst waters. Villány Mts., Buda Mts. $\left(\mathrm{g} \mathrm{dm}^{-3}\right)$.

\begin{tabular}{|l|l|l|l|l|l|l|}
\hline Lelöhely & $\mathbf{p H}$ & $\begin{array}{l}\mathbf{K}^{+} \\
\mathrm{mg} \mathrm{dm}^{-3}\end{array}$ & $\begin{array}{l}\mathbf{N a}^{+} \\
\mathrm{mg} \mathrm{dm}^{-3}\end{array}$ & $\begin{array}{l}\mathbf{M g}^{2+} \\
\mathrm{mg} \mathrm{dm}^{-3}\end{array}$ & $\begin{array}{l}\mathbf{H}_{2} \mathbf{S i O}_{3} \\
\mathrm{mg} \mathrm{dm}^{-3}\end{array}$ & Hivatkozás \\
\hline $\begin{array}{l}\text { Beremend, } \\
\text { Kisbarlang }\end{array}$ & 7,2 & 6,6 & 62 & 33,4 & & Dezső et al., 2007a \\
\hline $\begin{array}{l}\text { Beremend, } \\
\text { sportpálya }\end{array}$ & 7,2 & 6,5 & 61 & 33,5 & & Dezső et al., 2007a \\
$\begin{array}{l}\text { Kistapolca, } \\
\text { forrás }\end{array}$ & (savas) & 129,7 & 36 & 2,6 & $\begin{array}{l}\text { Rappné in } \\
\text { Fülöp, 1966, p.40. }\end{array}$ \\
\hline $\begin{array}{l}\text { Beremend, } \\
\text { vízakna kf. } \\
\text { udvarán }\end{array}$ & (savas) & 87,3 & 33,6 & 17,8 & $\begin{array}{l}\text { Rappné in } \\
\text { Fülöp, 1966, p.42. }\end{array}$ \\
\hline $\begin{array}{l}\text { Budai-hg. } \\
\text { karsztvizek }\end{array}$ & & & & & $10-20$ & Schulhof, 1957 \\
\hline
\end{tabular}


4. táblázat: Karsztvizek elemzési adatai. Villányi-hegység $\left(\mathrm{mol} \mathrm{dm} \mathrm{dm}^{-3}\right)$.

Table 4: Analytical data for karst waters. Villány Mts. $\left(\mathrm{mol} \mathrm{dm}^{-3}\right)$.

\begin{tabular}{|c|c|c|c|c|c|}
\hline Lelöhely & $\mathbf{p H}$ & $\begin{array}{c}\mathbf{K}^{+} \\
\mathrm{mol} \mathrm{dm}\end{array}$ & $\begin{array}{c}\mathbf{N a}^{+} \\
\mathrm{mol} \mathrm{dm}\end{array}$ & $\begin{array}{c}\mathbf{M g}^{2+} \\
\mathrm{mol} \mathrm{dm}\end{array}$ & $\begin{array}{c}\mathbf{H}_{4} \mathbf{S i O}_{4} \\
\mathrm{~mol} \mathrm{dm}^{-3}\end{array}$ \\
\hline $\begin{array}{c}\text { Beremend, } \\
\text { Kisbarlang }\end{array}$ & 7,2 & $1,69 \cdot 10^{-4}$ & $2,70 \cdot 10^{-3}$ & $1,37 \cdot 10^{-3}$ & - \\
\hline $\begin{array}{c}\text { Beremend, } \\
\text { sportpálya }\end{array}$ & 7,2 & $1,66 \cdot 10^{-4}$ & $2,65 \cdot 10^{-3}$ & $1,38 \cdot 10^{-3}$ & - \\
\hline $\begin{array}{c}\text { Kistapolca, } \\
\text { forrás }\end{array}$ & - & - & $5,64 \cdot 10^{-3}$ & $1,48 \cdot 10^{-3}$ & $3,33 \cdot 10^{-5}$ \\
\hline $\begin{array}{c}\text { Beremend, } \\
\text { vízakna kf. } \\
\text { Udvarán }\end{array}$ & - & - & $3,80 \cdot 10^{-3}$ & $1,38 \cdot 10^{-3}$ & $2,28 \cdot 10^{-4}$ \\
\hline
\end{tabular}

5. táblázat: Karsztvizek elemzési adatai. Villányi-hegység $\left(-\log \left(\mathrm{mol} \mathrm{dm}^{-3}\right)\right)$.

Table 5: Analytical data for karst waters. Villány Mts. $\left(-\log \left(\mathrm{mol} \mathrm{dm}^{-3}\right)\right)$.

\begin{tabular}{|c|c|c|c|c|c|}
\hline Lelőhely & pH & pK & pNa & pMg & $\mathrm{p}\left(\mathrm{H}_{4} \mathrm{SiO}_{4}\right)$ \\
\hline $\begin{array}{l}\text { Beremend, } \\
\text { Kisbarlang }\end{array}$ & 7,2 & 3,77 & 2,57 & 2,86 & \\
\hline $\begin{array}{l}\text { Beremend, } \\
\text { sportpálya }\end{array}$ & 7,2 & 3,78 & 2,58 & 2,86 & \\
\hline $\begin{array}{l}\text { Kistapolca, } \\
\text { forrás }\end{array}$ & & & 2,25 & 2,83 & 4,48 \\
\hline \multirow[t]{2}{*}{$\begin{array}{c}\text { Beremend, } \\
\text { vízakna kf. } \\
\text { Udvarán }\end{array}$} & & & 2,42 & 2,86 & 3,89 \\
\hline & pH & pH-pK & pH-pNa & 2pH-pMg & \\
\hline $\begin{array}{l}\text { Beremend, } \\
\text { Kisbarlang }\end{array}$ & 7,2 & 3,43 & 4,63 & 11,54 & \\
\hline $\begin{array}{l}\text { Beremend, } \\
\text { sportpálya }\end{array}$ & 7,2 & 3,42 & 4,62 & 11,54 & \\
\hline
\end{tabular}

Mindezek az adatok nem ideálisak a diagramok szerkesztésére. Az ionok és a kovasav elemzései nem ugyanabból a vízből készültek. Sajnos a Rappné-féle elemzéseknél nincs pH meghatározás, így ezeknél a $\mathrm{Na}$ és Mg kationok adatait sem lehet a diagramok szerkesztésére felhasználni. De az látszik, hogy a Mg tartalom a beremendi mintákkal csaknem megegyezik, a Na tartalom is hasonló, de valamivel nagyobb, mint a beremendi karsztvizekben. A kovasavra vonatkozó adatok ellenőrzése céljából a 3. táblázatban összehasonlításul a Budai-hegység hasonló karsztvizei elemzéseiböl (Schulhof, 1957) is megadtam a kovasav koncentrációinak körülbelüli határértékeit, amelyek különösen a kőfejtőből való adattal jól egyeznek. További pontatlanságot okoz, hogy az aktivitás értékek helyett közelítőleg csak a koncentráció értékeket tudjuk megadni. A koncentráció adatait $\mathrm{mol} \mathrm{dm}^{-3}$ egységekben a 4. táblázat, a szerkesztéshez szükséges $\mathrm{pH}, \mathrm{pK}, \mathrm{pNa}$ és $\mathrm{pMg}$ számított értékeket és ezek különbségeit, valamint $\mathrm{p}\left(\mathrm{H}_{4} \mathrm{SiO}_{4}\right)$ 
értékeit az 5. táblázat tartalmazza. Arra azonban így is megfelelnek ezek az adatok, hogy a diagramok alapján közelítőleg megadjuk a nekik megfelelő stabil ásványfázist.

$\mathrm{Az}$ adatokat szintén az 1-3. ábrák stabilitási diagramjain ábrázoltam (A 3. ábrán a beremendi vizeket ábrázoló vonal már lefelé nagyon kiesik a diagramból, igazi helye $\log \left(\mathrm{Na}^{+} / \mathrm{H}^{+}\right)=4,6$ értéknél volna.). Mind a három diagram szerint a karsztvíz összetétele egyértelmúen a kaolinit stabilitási tartományába esik, mégpedig annak is a kisebb kovasavtartalmú részébe, ahol már kvarc kiválására nem lehet számítani. Ugyanígy éppen hogy csak eléri a gibbsit metastabil mezejének a határát. Ugyanakkor valószínüleg a bemosott üledék összetételét már nem nagyon befolyásolta. A sokszor megjelenő cementáló kalcit azt jelzi, hogy a lazán bemosott agyag üregeit hamar kalcit cementálta, ami a víz további áramlását megakadályozta. Így valószínűbb, hogy az üledékanyag kaolinosodása az egykori felszínen történt, és a jelenleg a karsztos üregekben levő anyag különböző mértékben mállott összetétele a felszíni mállás különböző fokozatait tükrözi.

\section{Következtetések}

Mint a felsorolt példákból láttuk, a fizikai-kémiai szempontból hibátlanul és megbízható adatokból szerkesztett diagramok (pl. a Lippmann-féle diagramok javított változatai) jól jelzik a vizes oldatokkal egyensúlyban lévő ásványfázisokat. Adott vízösszetétel ismeretében elöre jelezhetők a várható fázisok, illetve fordítva: adott ásványos összetétel ismeretében következtetni lehet az azt létrehozó oldat összetételére.

A konkrét esetek elemzése viszont az értelmezés néhány nehézségére is rávilágított. A nehézségek egyik csoportja az ásványok stabilitásával kapcsolatos. A kaolinit és dickit keletkezési viszonyainak tisztázásakor a stabilitás önmagában nem ad elég magyarázatot arra, hogy mikor keletkezik az egyik, mikor a másik fázis, mert a nagy pontossággal megállapított Gibbs-féle képződési szabadenergia értékek esetén is a különbségek elhanyagolható nagyságúak maradnak. Máskor, mint például a többszörösen és különböző mértékben metastabil klorit/szmektit kevert szerkezetek esetében a számítások bonyolult volta miatt nem lehetséges a stabilitás pontosabb meghatározása, de itt éppen a földtani körülmények különbségeiből következtethetünk a stabilitási különbségekre.

Máskor az átalakulási reakciók lassú volta akadályozza a stabil ásvány-együttes kialakulását. A szikes talajok esetében az uralkodóan átörökölt ásvány-együttesben csak a meginduló átalakulások irányát (pl. talajtani szintek sorrendje, földpátok, muszkovit oldódása, klorit részleges stabilitása) és az újonnan keletkezett kis mennyiségü fázisokat (pl. kvarc, amorf kovasav, kaolinit, szmektit?) tudják magyarázni a diagramok. Máskor a lassú átalakulás éppen az előzőleg kialakult, közel stabil ásványtársulás megőrzését segíti elő. A beremendi kaolinos vörös agyagok intenzív mállással kialakult, egyensúlyhoz közeli összetételét a karsztvízzel való utólagos érintkezés már nem befolyásolta lényegesen.

\section{Hivatkozások}

Aihara, A., 1993: Organic geoscientific studies on diagenetic to burial metamorphic phenomena of sediments. Scientific Reports, Department of Earth and Planetary Sciences, Kyushu University 18, 1: 1-11. Fukuoka, Japan.

Aja, S.U., Rosenberg, P.E., 1992:The thermodynamic status of compositionally-variable clay minerals: a discussion. Clays and Clay Minerals, 40(3): 292-299.

https://doi.org/10.1346/CCMN.1992.0400307 
Bailey, S.W., 1982: Nomenclature for regular interstratifications. A report of the AIPEA Nomenclature Committee. Clays and Clay Minerals, 17(2): 243-248. https://doi.org/10.1180/claymin.1982.017.2.09

Benco, L., Tunega, D., Hafner, J., Lischka, H., 2001: Orientation of OH groups in kaolinite and dickite: ab initio molecular dynamics study. American Mineralogist, 86: 1057-1065. https://doi.org/10.2138/am-2001-8-912

Császár, G., 2005: Magyarország és környezetének regionális földtana I. Paleozoikumpaleogén. ELTE Eötvös Kiadó. Budapest. 328p. ISBN 963-463-744-2

Cuadros, J., Vega, R., Toscano, A., Arroyo, X., 2014: Kaolinite transformation into dickite during burial diagenesis. American Mineralogist, 99(4): 681-695.

https://doi.org/10.2138/am.2014.4614

Devidal, J.-L., Dandurand, J.-L., Gout, R., 1996: Gibbs free energy of formation of kaolinite from solubility measurement in basic solution between 60 and $170 \mathrm{C}^{\circ}$. Geochimica et Cosmochimica Acta, 60: 553-564. https://doi.org/10.1016/0016-7037(95)00430-0

Dezső, J., Kovács, B., Máté, K., 2007a: Jelentés a Duna-Dráva Cement Kft. Beremendi bányaüzem területén a jövesztés során esetlegesen fellépő nitrátszennyeződés lehetséges terjedéséről és a kőfejtő környezetének nitrátterheléséről. Kézirat. Pécs. 27p.

Dezső, J., Raucsik, B., Viczián, I., 2007b: Villányi-hegységi karsztos hasadékkitöltések szemcseösszetételi és ásványtani vizsgálata (Granulometric and mineralogical analysis of karstic fissure filling sediments in Villány Mts., S Hungary). Acta GGM Debrecina, Geology, Geomorphology, Physical Geography Ser. 2: 151-180. ISSN: 1788-4497.

Eskola, P., 1921: The mineral facies of rocks. Norsk Geologisk Tidsskrift (The Norwegian Journal of Geology), 6 (1920-21): 143-194.

http://www.geologi.no/images/NJG_articles/NGT_06_1_2_143-194.pdf

Fialips, C.-I., Navrotsky, A., Pett, S., 2001: Crystal properties and energetics of synthetic kaolinite. American Mineralogist, 86: 304-311. https://doi.org/10.2138/am-2001-2-313

Fialips, C.-I., Majzlan, J., Beaufort, D., Navrotsky, A., 2003: New thermochemical evidence on the stability of dickite vs. kaolinite. American Mineralogist, 88: 837-845. https://doi.org/10.2138/am-2003-5-612

Fülöp, J., 1966: A Villányi-hegység krétaidőszaki képződményei. Geologica Hungarica. Series Geologica, 15: 1-131.

http://epa.oszk.hu/02900/02986/00017/pdf/EPA029686_geologica_hungarica_ser_geol_15 1966.pdf

Garrels, R.M., Christ, C. L., 1965: Solutions, minerals, and equilibria. Harper and Row, New York. $450 \mathrm{p}$.

Giese, R. F.jr., 1973: Interlayer bonding in kaolinite. Clays and Clay Minerals, 21: 145-149. ISSN: 0009-8604 (Print) 1552-8367 (Online), http://citeseerx.ist.psu.edu/viewdoc/download?doi=10.1.1.581.7134\&rep=rep1\&type=pdf https://doi.org/10.1346/CCMN.1973.0210302

Helgeson, H.C., Garrels, R.M., Mackenzie, F.T., 1969: Evaluation of irreversible reactions in geochemical processes involving minerals and aqueous solutions. II. Applications.

Geochimica et Cosmochimica Acta, 33 : 455-481.

https://www.sciencedirect.com/journal/geochimica-et-cosmochimica-acta/vol/33/issue/4 https://doi.org/10.1016/0016-7037(69)90127-6

Hemingway, B.S., Robie, A.R., 1977: Enthalpies of formation of low albite ( $\left.\mathrm{NaAlSi}_{3} \mathrm{O}_{8}\right)$, gibbsite $\left(\mathrm{AI}\left(\mathrm{OH}_{3}\right)\right.$, and $\mathrm{NaAlO}_{2}$; Revised values for $\Delta \mathrm{H}_{\mathrm{f}, 298}^{\circ}$ and $\Delta \mathrm{G}_{\mathrm{f}, 298}^{\circ}$ of some aluminosilicate minerals. Journal of Research of the U. S. Geological Survey, 5: 413-429. https://pubs.usgs.gov/journal/1977/vol5issue4/report.pdf 
Kapoor, B.S., Rózsavölgyi, J., Rédly, M., 1986: Study of physico-chemical properties and mineral compositions of salt-affected and meadow soils. Agrokémia és Talajtan, 35: 317340. Print ISSN 0002-1873

Kiseleva, A., Orogodova, L.P., Krupskaya, V.V., Melchakova, L.V., Vigasina, M.F., Luse, I. 2011: Thermodynamics of the kaolinite-group minerals. Geochemistry International, 49(8): 793-801. https://doi.org/10.1134/S001670291106005X

Koch, S., Sztrókay, K.I., 1967: Ásványtan. - 2. átdolgozott kiadás, I-II. kötet. Tankönyvkiadó. Budapest. 936 p. Tankönyvi szám: 42129.

Korpás, L., 1980: Felsőtriász korú bauxitindikációk a Dunántúli-középhegységben. MÁFI Évi Jelentés. 1978-ról 197-203.

[Korzsinszkij, D.Sz.] Коржинский, Д. С. (Koržinskij, D. S.) 1936: Подвижность и инертность компонентов при метасоматозе (Mobility and inertness of components in metasomatosis). - Известия АН СССР Серия Геология 1936(1), 35-60.

[Korzsinszkij, D.Sz.] Коржинский, Д. C. (Koržinskij, D. S.) 1957: Физико-химиические основы анализа парагенезисов минералов. Издательство Академии Наук СССР. Москва. 184 стр.

Kübler, B., 1984: Les indicateurs des transformations physiques et chimiques dans la diagenèse. Températures et calorimétrie. In Lagache, M. (ed.): Thermométrie et barométrie géologiques 2(14), Société française de minéralogie et de cristallographie, Paris.

Lanson, B., Beaufort, D., Berger, G., Bauer, A., Cassagnabere, A., Meunier, A., 2002: Authigenic kaolin and illite minerals during burial diagenesis of sandstones: a review. Clay Minerals, 37: 1-22. https://doi.org/10.1180/0009855023710014

Ligny, D., de Navrotsky, A., 1999: Energetics of kaolin polymorphs. American Mineralogist, 84: 506-516. https://doi.org/10.2138/am-1999-0404

Lippmann, F., 1954: Über einen Keuperton von Zaiserweiher bei Maulbronn. Beiträge zur Mineralogie und Petrographie, 4: 130-134. https://doi.org/10.1007/BF01111150

Lippmann, F., 1979: Stabilitätsbeziehungen der Tonminerale. Neues Jahrbuch für Mineralogie - Abhandlungen (Journal of Mineralogy and Geochemistry), 136(3): 287-309. ISSN 0077-7757, e-ISSN 2363-7161

Lippmann, F., 1982: The thermodynamic status of clay minerals. - In van Olphen, H., Veniale, F. (ed.): $7^{\text {th }}$ International Clay Conference, Bologna and Pavia, 1981, 475-485. Developments in Sedimentology 35, Elsevier. Amsterdam etc.

Lippmann, F., 1991: Aqueous solubility of magnesian calcites with different endmembers. Acta Mineralogica-Petrograhica Szeged, 32: 5-19. HU ISSN 0365-8066, HU ISSN 0324-6523, http://acta.bibl.u-szeged.hu/24788/1/mineralogica 032 005-019.pdf

Nemecz, E., 2006: Ásványok átalakulási folyamatai talajokban. Akadémiai Kiadó. Budapest. 326p. ISBN: 9630582988

Ruiz Cruz, M.D., 2007: Genesis and evolution of the kaolin-group minerals during the diagenesis and the beginning of metamorphism. In Nieto, F., Jiménez-Millán, J. (eds.): Diagenesis and Low-Temperature Metamorphism. Theory, Methods and Regional Aspects. Seminarios de la Sociedad Española de Mineralogía, 3: 41-52. https://pdfs.semanticscholar.org/af0a/bafa13e217a2b8a56a08d1 e0682ed8356566.pdf?.ga= 2.85554975.74143947.1576416616-584750445.1511181602

Sato, H., Ono, K., Johnston, C.T., Yamagishi, A., 2004: First-principle study of polytype structures of 1:1 dioctahedral phyllosilicates. American Mineralogist, 89(11-12): 1581-1585. https://doi.org/10.2138/am-2004-11-1201

Schulhof, Ö. (szerk.), 1957: Magyarország ásvány- és gyógyvizei. Akadémiai Kiadó, Budapest. 963p. N 1542 
Stefanovits, P., Dombóvári, L., 1986: The mineral composition of soils showing the major characteristics of their formation and dynamics. A Gödöllöi Agrártudományi Egyetem Évkönyve. Bulletin of the University of Agricultural Sciences, Gödöllö, 1: 5-15.

Szabolcs, I., Szendrei, G., 1980: A szilíciumvegyületek különböző formái és eloszlásuk szology és szologyos talajokban. Agrokémia és Talajtan, 29: 167-182.

https://rive.google.com/drive/folders/1zj51M2NCaT60ysGhnCUvVO4kesu7-p1D

Szendrei, G., 1981: An approach to estimating mineral stability in salt affected soils. Agrokémia és Talajtan, 30: 63-72. ISSN 0002-1873. http://real.mtak.hu/97297/1/at_1981_30_SUPP_63-72.pdf

Szendrei, G., 1985: The stability and distribution of clay minerals in Hungarian salt affected soils. In: 5th Meeting of the European Clay Groups, Prague, 471-476.

Szendrei, G., 2017: Agyagásványok szikes talajokban. In Kubovics I., Póka T., Weidinger T. (szerk.): A talajtakaró geonómiája. A pedoszféra mint a Föld sajátos fázishatára. Az MTA Geonómiai és Planetológiai Albizottságának konferenciája, 2013, 85-106. ISSN 08657920ISBN, 978-963-284-918-8(online) http://nimbus.elte.hu/oktatas/metfuzet/EMF028/EMF28.pdf

Udvardi, B., Kovács, I., Viczián, I., Hámor-Vidó, M., Mihály, J., Németh, Cs., 2013: The correlation of attenuated total reflectance infrared (ATR-FTIR) spectroscopic data with Xray diffraction (XRD) parameters and its potential use for mineral identification and quantification in drilling cores: examples from the Pannonian Basin, Hungary (abstract). Geophysical Research Abstracts, 15: EGU2013-10585-1, EGU General Assembly, Vienna, 2013. https://www.geophysical-research-abstracts.net/egu2013.html

Varga, A., 2019: Híd a kémiához. A földtudományok általános, szervetlen és fizikai kémiai alapjai. Egyetemi tankönyv (elektronikus tananyag), Szegedi Tudományegyetem, TTIK Földrajzi és Földtudományi Intézet. Szeged. 305p. http://eta.bibl.u-szeged.hu/2088/ https://doi.org/10.14232/eta.2019.2088

Viczián, I., 1992: Diagenetic neoformations in Middle Triassic evaporitic and carbonate rocks, Mecsek Mts. (S. Hungary). Acta Mineralogica-Petrograhica Szeged, 33: 13-24. HU ISSN 0365-8066, HU ISSN 0324-6523. http://acta.bibl.uszeged.hu/39411/1/mineralogica 033.pdf

Viczián, I., 1995: Clay mineralogy of Jurassic carbonate rocks, Central Transdanubia, Hungary. Acta Geologica Hungarica, 38(3): 251-268. ISSN 0236-5278, http://realj.mtak.hu/2990/1/ActaGeologica_38.pdf

Viczián, I., 2002: Mineralogy of Pliocene to Pleistocene pelitic sediments of the Great Hungarian Plain. Acta Mineralogica-Petrograhica Szeged, 43: 39-53.

HU ISSN 0365-8066, http://acta.bibl.u-szeged.hu/39424/1/mineralogica_043.pdf

Viczián, I., 2006: A Lippmann-féle stabilitási diagramok jelentősége az agyagásványok képződési viszonyainak értelmezésében. Acta GGM Debrecina, Geology, Geomorphology, Physical Geography Series, 1: 39-50. https://docplayer.hu/46450125-Acta-ggm-debrecinageology-geomorphology-physical-geography-series-debrecen-vol-1-pp.html

Viczián, I., 2006-2007: Mineralogy of Pliocene to Middle Pleistocene red clays in SE Transdanubia (Hungary). Review of the quantitative data. Acta Mineralogica-Petrograhica Szeged, 47: 25-46. HU ISSN 0365-8066. http://acta.bibl.uszeged.hu/39429/1/mineralogica 047.pdf

Viczián, I., 2008: A termodinamika alkalmazása az üledékes kőzettanban (előadás). Téli Ásványtudományi Iskola, Balatonfüred.

Viczián, I., 2009: Karbonát-ásványok stabilitási viszonyai vizes oldatokban (előadás). Téli Ásványtudományi Iskola, Balatonfüred.

Viczián, I., 2011: A kémiai termodinamika kőzettani alkalmazásának története (előadás). Magyar Geo- és Chemo-történettudományi Konferencia, Budapest, MÁFI. 
Viczián, I., 2015: Diasporic bauxite in the Villány-Bihor structural unit, in deeply subsided basement position (abstract). 6th Mineral Sciences in the Carpathians Conference, Veszprém, 2015. Acta Mineralogica-Petrograhica. Szeged, Abstract Ser., 9: 71. HU ISSN 0324-6523HU, ISSN1589-4835, http://real.mtak.hu/33160/1/Patko et al_MSCC 2015.pdf

Viczián, I., 2019: Dickit előfordulása és stabilitási viszonyai a Pannon-medence aljzatában (előadás). Ásványtudományi Téli Iskola, Veszprém.

Viczián, I., Kovács, I., Udvardi, B., 2013: Dickit a Középdunántúli-egység középső-triász karbonátos kőzeteiben (Som-1. fúrás) (előadás). MFT Agyagásványtani Szakosztály, Budapest.

Viczián, I., Kovács-Pálffy, P., 1997: Regularly mixed-layer $14 \AA$ clay minerals in marls of a Lower Cretaceous clastic sequence, Gerecse Mts., Hungary. Geologica Carpathica, Series Clays, 6(2): 97-105. Online ISSN 1336-8052

Wilson, M.J., 2013: Rock-Forming Minerals, vol. 3c, Sheet Silicates-Clay Minerals. 2nd edition. Geological Society. London. 724p. ISBN-13: 978-1862393592

Zotov, A., Mukhamet-Galeev, A., Schott, J., 1998: An experimental study of kaolinite and dickite relative stability at $150-300{ }^{\circ} \mathrm{C}$ and the thermodynamic properties of dickite. American Mineralogist, 83:516-524. https://doi.org/10.2138/am-1998-5-610 https://pdfs.semanticscholar.org/ed96/6536ea6558aecedb2da8e507feb8e18f7b99.pdf 